УДК 656.61

\author{
A.D. ABRAMOV \\ Kherson National Technical University \\ G.S. ABRAMOV \\ Kherson State Maritime Academy
}

\title{
ANALYSIS OF MATHEMATICAL MODELS OF MARITIME SHIPPING TRENDS IN A CRISIS ENVIRONMENT
}

The maritime shipping sector has a considerable influence in socioeconomic development and investment potential of governments. Graphs of maritime shipping growth trends show a considerable decline related to the global economic crisis of 2008-2009, and the picture after the ongoing COVID crisis shows very similar figures. This shows that although maritime shipping overall has a positive growth outlook, there is an uncertainty regarding the stability of economical growth and related consequences for the maritime shipping sector. This uncertainty first of all is due to geopolitical and economic risks from trade politics and structural shifts, such as economics rebalancing in China, the decline in growth of global production-supply chains, changes in the global energetic balance, and the ongoing crisis. Also contributing to this is the emergence of new tendencies, in particular the spread of digital technologies which may change the face of maritime shipping as well as the streams and patterns of maritime shipping. It is still unclear how these factors would develop and how they would support or restrict the growth in maritime shipping. Even so, the long-term outlook for global container shipping volumes remains positive. Still, it is evident that further monitoring and evaluation is required. In this case, a closer look at the maritime shipping dynamics across various cargo types allows for a clearer picture of how maritime shipping can continue to develop. To that end, based on statistics on various maritime cargo shipments, we have performed a regression-correlation analysis and received linear regression equations which describe shipping trends of chemical products, liquids, container shipments, and other cargo types. The regression analysis is based on statistics from 2000-2018, so the forecast for the following years is done with the assumption that the same conditions persist. Recent events (the COVID-19 pandemic and the global crisis it caused) are force-majeure conditions, which would ultimately disrupt the forecast. Forecasting in this regard can be resumed when factual values for the decline in 2020-2021 would be made known.

Keywords: maritime shipping, mathematical models, statistics, forecast.

\author{
О.Д. АБРАМОВ \\ Херсонський Національний Технічний Університет \\ Г.С. АБРАМОВ \\ Херсонська Державна Морська Академія
}

\section{АНАЛІЗ МАТЕМАТИЧНИХ МОДЕЛЕЙ ТРЕНДІВ МОРСЬКИХ ВАНТАЖОПЕРЕВЕЗЕНЬ У КРИЗОВИХ УМОВАХ}

Сфера морських перевезень значно впливає на соичіально-економічний розвиток $і$ інвестиційний потенціал держав. На графіках трендів росту вантажоперевезень чітко помітний спад, пов'язаний зі світовою економічною кризою 2008-2009 року, і поточна криза у зв'язку з COVID має дуже схожі показники. Це говорить про те, щчо, хоча перспективи розвитку морських перевезень у цілому представляються позитивними, існує невизначеність відносно стійкості економічного пожвавлення й пов'язаних із циим наслідків для сектору морських перевезень. Така невизначеність значною мірою обумовлена комбінацією геополітичних і економічних ризиків, торговельною політикою й структурними зрушеннями, такими як перебалансування економіки Китаю, уповільнення росту глобальних виробничозбутових ланџюжків, зміни у світовому енергетичному балансі і поточна криза. Цьому сприяє також поява нових тенденщій, зокрема поширення циифрових технологій, які можуть змінити вигляд світового судноплавства, потоки й схеми морських перевезень. Як і раніше, неясно, як ці фактори будуть розвиватися $і$ у якому степені вони будуть підтримувати або стримувати процес пожвавлення росту морських перевезень. Очевидно, щз вони потребують подальшого моніторингу й очінки. Однак більш уважний аналіз динаміки морських перевезень по окремих видах вантажів дозволяє одержати більш чітку уяву про зміни в їхній інтенсивності. Для иього на основі статистики по вантажообігу окремих видів морських вантажів проведений регрессійно-кореляційний аналіз $і$ отримані рівняння лінійних регресій, щу описують тренди зростання вантажсобігу хімічних продуктів, наливних вантажів, 
контейнерних перевезень і інших типів вантажів. Аналіз базується на статистииі 2000-2018 років, тому прогноз на наступні роки виконаний з припущенням збереження умов його реалізації. Події останнього часу (пандемія COVID-19 і обумовлена нею світова економічна криза) є форс-мажорними обставинами, щчо, природно, порушить прогноз. Прогноз у цъьому випадку може бути відновлений, коли будуть відомі фактичні об'єми спаду в 2020-2021 роках.

Ключові слова: морські перевезення, математичне моделювання, статистика, прогнози.

\author{
А.Д. АБРАМОВ \\ Херсонский Национальный Технический Университет \\ Г.С. АБРАМОВ \\ Херсонская Государственная Морская Академия
}

\title{
АНАЛИЗ МАТЕМАТИЧЕСКИХ МОДЕЛЕЙ ТРЕНДОВ МОРСКИХ ГРУЗОПЕРЕВОЗОК В КРИЗИСНЫХ УСЛОВИЯХ
}

\begin{abstract}
Сфера морских перевозок значительно воздействует на социально-экономическое развитие и инвестиционный потенциал государств. На графиках трендов роста грузоперевозок отчетливо виден заметный спад, связанный с мировым экономическим кризисом 2008-2009 года, и текущий кризис в связи с COVID имеет очень похожие показатели. Это говорит о том, что, хотя перспективы развития морских перевозок в целом представляются позитивными, существует неопределенность в отношении устойчивости экономического оживления и связанных с этих последствий для сектора морских перевозок. Такая неопределенность в значительной мере обусловлена сочетанием геополитических и экономических рисков, проводимой торговой политикой и структурными сдвигами, такими как перебалансировка экономики Китая, замедление роста глобальных производственно-сбытовых цепочек, изменения в мировом энергетическом балансе и текущий кризис. Этому способствует также появление новых тенденций, в частности, распространение цифрровых технологий, которые могут изменить облик мирового судоходства, потоки и схемы морских перевозок. По-прежнему неясно, как эти факторы будут развиваться и в какой степени они будут поддерживать или сдерживать процесс оживления роста морских перевозок. Очевидно, что они потребуют дальнейшего мониторинга и оценки. Однако более пристальный анализ динамики морских перевозок по отдельным видам грузов позволяет получить более четкое представление об изменениях в их интенсивности. Для этого на основе статистики по грузообороту отдельных видов морских грузов проведен регрессионнокорреляционный анализ и получены уравнения линейных регрессий, описывающчи тренды роста грузооборота химических продуктов, наливных грузов, контейнерных перевозок и других типов грузов. Анализ основан на статистике 2000-2018 годов, поэтому прогноз на последующие годы выполнен в предположении сохранения условий его реализации. События последнего времени (пандемия COVID-19 и обусловленный ею мировой экономический кризис) являются форс-мажорными обстоятельствами, что, естественно, нарушит прогноз. Прогноз в этом случае может быть возобновлен, когда будут известны фактические объемы спада в 2020-2021 годах.
\end{abstract}

Ключевые слова: морские перевозки, математическое моделирование, статистика, прогнозы.

\section{Problem statement}

With multiple factors heavily affecting the volatility of the global market, not least among them the COVID-19 pandemic, there is a great deal of uncertainty as to the impact said factors will have on maritime shipping, with over $80 \%$ of global transportation hinging on naval transport. To set appropriate expectations and enable future planning, analysis and forecasting must be performed to predict the situation that is developing.

\section{Analysis of latest research and publications}

Analyses by the UNCTAD (United Nations Conference on Trade and Development) show consistent growth of global maritime shipping, which will depend on further improvement of global economical conditions [1]. Also, graphs of maritime shipping growth trends show a considerable decline related to the global economic crisis of 2008-2009, and the picture after the ongoing COVID crisis shows very similar figures. This shows that although maritime shipping overall has a positive growth outlook, there is an uncertainty regarding the stability of economical growth and related consequences for the maritime shipping sector. 
This uncertainty first of all is due to geopolitical and economic risks from trade politics and structural shifts, such as economics rebalancing in China, the decline in growth of global production-supply chains, changes in the global energetic balance, and the ongoing crisis. Also contributing to this is the emergence of new tendencies, in particular the spread of digital technologies which may change the face of maritime shipping as well as the streams and patterns of maritime shipping. It is still unclear how these factors would develop and how they would support or restrict the growth in maritime shipping. It is evident that further monitoring and evaluation is required. However, a closer look at the maritime shipping dynamics across various cargo types allows for a clearer picture of the scale of such growth.

\section{The goal of this work}

The goal is to analyze developments in maritime shipping and build mathematical models based on the statistical data in [1], [2], which would describe the growth of maritime shipping and provide forecasts (in bln ton-miles and percent) for throughput of each individual cargo type.

\section{Main section}

The maritime shipping sector has a considerable influence in socioeconomic development and investment potential of governments. Acting as a global resource distribution complex, international shipping connects manufacturing capacities to international consumer markets [4,5]. Despite the COVID crisis, the global economy keeps striving to recover and gradually diversify shipping streams. The largest throughput in the Pacific is seen in the North American consumer markets, importing mainly high added-value good. Raw material exports into Asian countries also balances out the tonnage. Under the volatile demand conditions, cargo streams in other regions are expecting only minor growth after the recession. Even so, the long-term outlook for global container shipping volumes remains positive.

The global tendencies that continue to definite the dynamics in container shipping is the volatility in consumer demand and the excess supply of line shipping as a product. These tendencies are the result of the continued growth of the line shipping fleet. In just February of 2017 , container line shipping was being handled by over 6.000 vessels with a capacity of 255.480.383 tons which translates into 20.650.250 TEU, including 5.108 specialised vessels reserved for ISO-containerised cargo.

The largest container ship at the time had been OOCL Hong Kong, its 21.000+ TEU capacity considered to be almost at the limit of what could be possible, as it approached the capacity of the Suez Canal. Despite the safety concerns about the continuing size race among container vessels, several even larger container ships have entered service since then, including HMM Algeciras, the current largest container ship with a capacity of 23.964 TEU. The aforementioned safety concerns were not unfounded, given the infamous Suez Canal incident with the vessel Ever Given at its 20.124 TEU.

UNCTAD's review points out that in 2017 growth rates in maritime shipping went up and reached 4\%, which is the highest rate in the last five years [1]. Thanks to the revitalization of the global economy and expansion of international trade, the volume of global maritime shipping has reached an estimate 10.7 billion tons, wherein almost half of said growth is owed to dry bulks and container shipments. After low growth rates over the previous two years, the volume of container shipping has increased in 2017 by $6.4 \%$. At the same time, dry bulk shipping has grown by $4 \%$ compared to the $1.7 \%$ in 2016 . Raw oil shipping has grown by $2.4 \%$ compared to the $4 \%$ of 2016 , whereas oil product and gas shipments have grown by a $3.9 \%[3]$. 
Although many of these same trends have persisted over the years, the picture changed dramatically for the short term in 2020 . With 2019 showing some of the lowest performance indicators since the 2008-2009 crisis already, the COVID pandemic in 2020 has severely impacted the global economy, and inevitably that impact was shared by the maritime shipping industry. Facing a decline of roughly $4 \%$ in volume, recent UNCTAD projections point to a recovery of $4.8 \%$ in the following year, although whether or not these figures would hold depends on a plethoora of factors that can significantly impact the actual figure.

Further shaping the maritime shipping dynamics are the trade tensions between major global economies, with uncertainty in regard to policies, and overall trends towards trade protectionism noot only in the US but also in Europe. Although several steps have been made in 2020 to remedy these tensions to a certain degree (trade talks between the US and China, as well as between the UK and the European Union), their effectiveness remains to be seen.

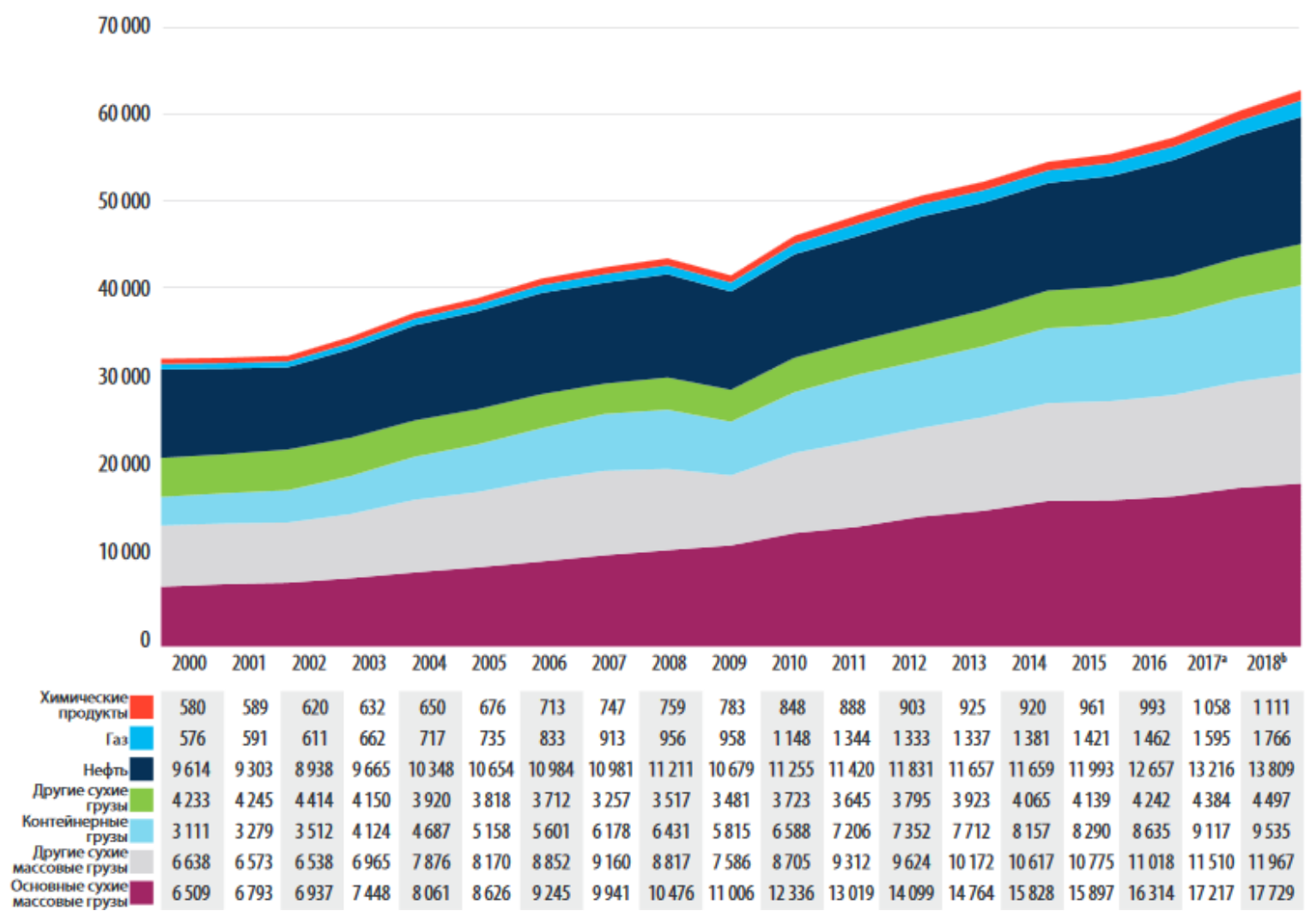

Fig. 1. Maritime shipping throughput divided by cargo types, 2000-2018 (bln ton-miles) [1]

Based on Clarksons Research statistics on various maritime cargo shipments in 20002018, we have performed a regression-correlation analysis and received linear regression equations which describe shipping trends of chemical products, liquids, container shipments, and other cargo types.

For chemical products:

$$
\mathrm{Y}_{1}=(549.2 \pm 9.3)+(28.777 \pm 0.885) X ; \mathrm{R}^{2}=0.984 ; \sigma=21.1
$$

For natural gas:

$$
\mathrm{Y}_{2}=(477.8 \pm 29.8)+(65.851 \pm 2.825) X ; \mathrm{R}^{2}=0.970 ; \sigma=67.4
$$

For oil: 


$$
\mathrm{Y}_{3}=(9207.7 \pm 180.5)+(215.95 \pm 17.13) X ; \mathrm{R}^{2}=0.903 ; \sigma=408.9 .
$$

For container shipments:

$$
\mathrm{Y}_{4}=(3177.1 \pm 119.0)+(351.59 \pm 11.29) X ; \mathrm{R}^{2}=0.983 ; \sigma=269.6 .
$$

For mainline dry bulks:

$$
\mathrm{Y}_{5}=(5591.8 \pm 194.3)+(678.37 \pm 18.44) X ; \mathrm{R}^{2}=0.988 ; \sigma=440.4
$$

For other dry shipments:

$$
\mathrm{Y}_{6}=(6374.0 \pm 222.1)+(291.05 \pm 21.08) X ; \mathrm{R}^{2}=0.918 ; \sigma=503.4 .
$$

For the overall shipments:

$$
\mathrm{Y}_{7}=(25377.7 \pm 500.3)+(1631.6 \pm 47.5) X ; \mathrm{R}^{2}=0.986 ; \sigma=1133.8,
$$

where $\mathrm{R}^{2}$ is the determination coefficient,

$\sigma-$ standard deviation (standard error),

$\mathrm{X}=$ current year -2000 .

Regression formulae display standard errors for coefficients.

Each model has a high rate of adequacy, as the determination coefficient is close to 1, and have a comparatively low standard error for the regression, which ensures an acceptable accuracy of the estimation.

The regression models received allow for an evaluation of the yearly growth in the throughput of corresponding cargo type (pessimistic and optimistic estimates):

for chemicals, 27.9 to 29.7 bln ton-miles;

for natural gas, 63 to 68.7 bln ton-miles;

for crude oil, 198.8 to 233.1 bln ton-miles;

for container shipments, 340.3 to 362.9 bln ton-miles;

for mainline dry bulks, 659.9 to 696.81 bln ton-miles;

for other dry shipments, 270 to 312.1 bln ton-miles;

for overall volume of shipments, 1584.1 to 1679.1 bln ton-miles. 



Fig. 2. Linear regressions of chemical, natural gas, and oil shipment growth, 2000-2018 (bln ton-miles) 


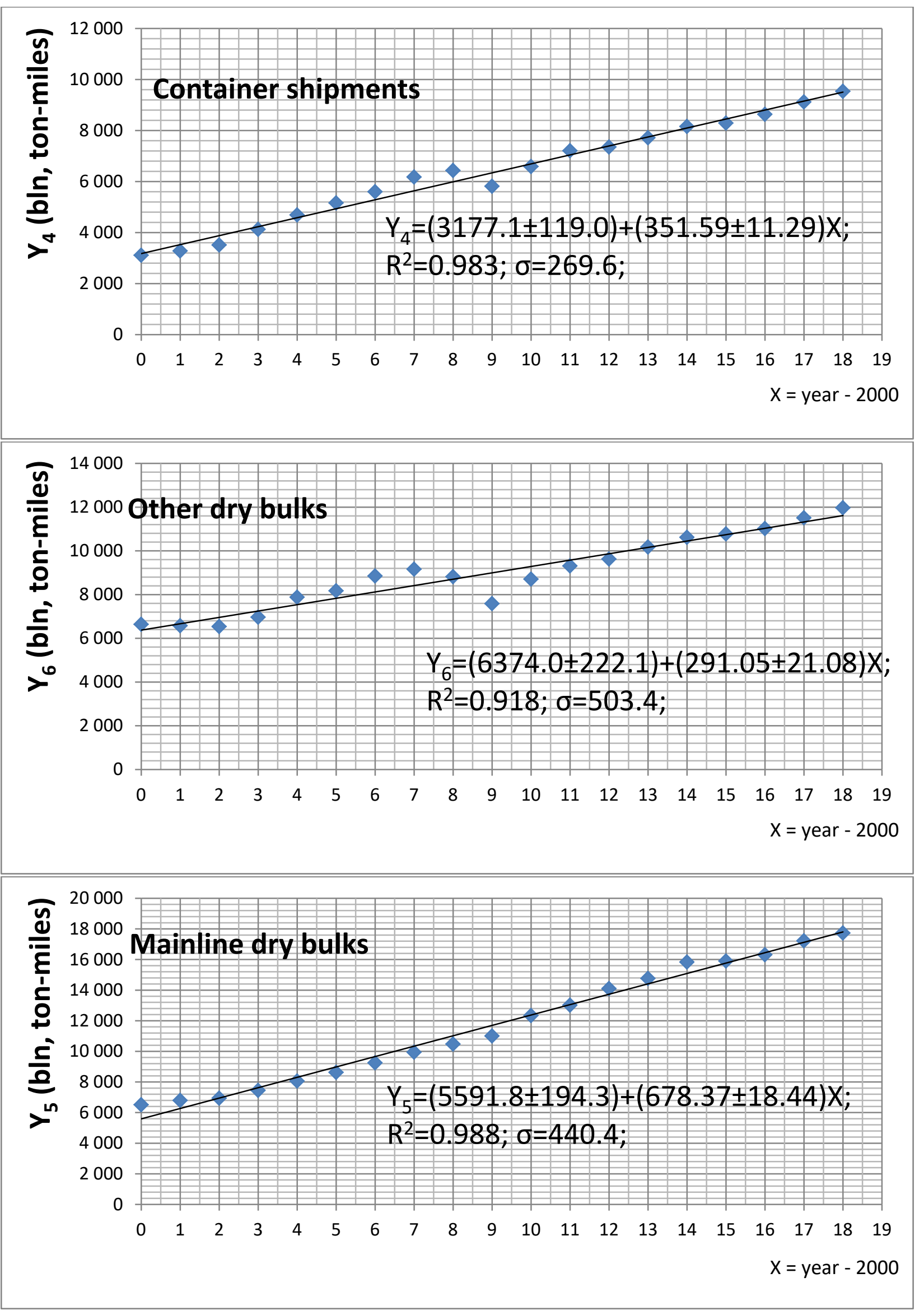

Fig.3. Linear regressions of container and dry bulk shipment growth, 2000-2018 (bln ton-miles) 
Based on the models received we can also perform forecasting (extrapolation) for volumes of maritime shipments in the following years. The corresponding estimates show that for the period of 2019-2023, shipment volumes in the following cargo types would grow to the following rates:

for chemicals, $2.4 \%-2.6 \%$;

for natural gas, $3.4 \%-3.8 \%$;

for crude oil, $1.5 \%-1.6 \%$;

for container shipments, $3.2 \%-3.6 \%$;

for mainline dry bulks, $3.3 \%-3.7 \%$;

for other dry shipments, $2.3 \%-2.4 \%$;

for overall volume of shipments, $2.7 \%-2.9 \%$.

\section{Conclusions}

Based on the models above, throughout 2019-2023 the total average growth rates for global maritime shipping will be between $1.5 \%$ and $3.8 \%$. The shipment volume is expected to rise across all sectors, with the biggest growths in container and dry bulk shipments. Shipments of liquids are also expected to grow, albeit slower than other market segments, which agrees with the tendencies seen earlier.

The above regression analysis is based on statistics from 2000-2018, so the forecast for the following years is done with the assumption that the same conditions persist. Recent events (the COVID-19 pandemic and the global crisis it caused) are force-majeure conditions, which would ultimately disrupt the forecast.

However, analysis of the events following the economic crisis of 2008-2009 shows that after a break in the curve (a more or less sharp decline) the growth in maritime shipment resumes at almost the same rate.

Thus, after an inevitable decline in maritime shipping in 2020-2021, there is hope for its continued growth at the rates previously seen. Forecasting in this regard can be resumed when factual values for the decline in 2020-2021 would be made known.

\section{Список литературы}

1. UNCTAD Review of Maritime Transport 2018 (UNCTAD/RMT/2018), United Nations Publications. URL: https://unctad.org/en/PublicationsLibrary/rmt2018_ru.pdf (access date - 28.10.2019).

2. Clarksons Research. London: Clarksons Research Services Ltd., 2017. URL: https://www.crsl.com / (access date - 28.10.2019).

3. Siba E. Sow M. Strengthening regional value chains: What's the role of the African Continental Free Trade Agreement? Africa in Focus. Washington: Brookings Institution, 2018. URL: https://www.brookings.edu/blog/africa-in-focus/2018/03/21/strengtheningregional-value-chains-whats-the-role-of-the-african-continental-free-trade-agreement/ (access date - 28.10.2019) .

4. Курганов В.М., Миротин Л.Б. Международные перевозки / под ред. Л.Б.Миротина. М.: Издательский центр «Академия», 2011. 304 с.

5. Тюленев К.Г. Управление контейнерными перевозками во внешнеэкономической деятельности. СПб.: ИПТ РАН, 2017. 112 с. 


\section{References}

1. UNCTAD Review of Maritime Transport 2018 (UNCTAD/RMT/2018), United Nations Publications. URL: https://unctad.org/en/PublicationsLibrary/rmt2018_ru.pdf (access date - 28.10.2019).

2. Clarksons Research. London: Clarksons Research Services Ltd., 2017. URL: https://www.crsl.com/ (access date - 28.10.2019).

3. Siba, E. \& Sow, M. (2018). Strengthening regional value chains: What's the role of the African Continental Free Trade Agreement? Africa in Focus. Washington: Brookings Institution. URL: https://www.brookings.edu/blog/africa-in-focus/2018/03/21/ strengthening-regional-value-chains-whats-the-role-of-the-african-continental-free-tradeagreement/ (access date - 28.10.2019) .

4. Kurganov, V.M. \& Mirotin, L.B. (2011). Mezhdunarodnyie perevozki: uchebnik dlya stud. uchrezhdeniy vyissh. prof. obrazovaniya / pod red. L.B.Mirotina. M.: Izdatelskiy tsentr «Akademiya».

5. Tyulenev, K.G. (2017). Upravlenie konteynernyimi perevozkami vo vneshneekonomicheskoy deyatelnosti. SPb.: IPT RAN.

Абрамов Алексей Дмитриевич - аспирант кафедры информационных технологий Херсонского Национального Технического Университета, eredale@gmail.com.

Абрамов Геннадий Серафимович - к. ф.-м. н., доцент кафедры судовождения Херсонской Государственной Морской Академии (0677891001, gennadabra@gmail.com, ORCID 0000-0003-0333-8819). 